\title{
Paddy Straw and Maize Stalks Compost for Cultivation of Agaricus bisporus
}

\author{
Sukhmandeep Kaur*, Mehakpreet Kaur, Rajni Devi and Shammi Kapoor
}

Department of Microbiology, Punjab Agricultural University, Ludhiana-141001, India

*Corresponding author

\begin{tabular}{|l|}
\hline Ke y w o r d s \\
$\begin{array}{l}\text { Agaricus bisporus, } \\
\text { Paddy straw, Maize } \\
\text { stalk, Composting, } \\
\text { Proximate analysis }\end{array}$ \\
\hline Article Info \\
\hline $\begin{array}{l}\text { Accepted: } \\
\text { 17 December } 2018 \\
\text { Available Online: } \\
\text { 10 January } 2019\end{array}$ \\
\hline
\end{tabular}

\section{Introduction}

Mushrooms have been considered as ingredient of gourmet cuisine across the globe; especially for their unique flavor and have been valued by humankind as a culinary wonder. Generally, edible mushrooms are used not only for their nutritional value but are now in demand for their medicinal properties
Composting is carried out under aerobic thermogenesis to prepare a selective substrate for Agaricus bisporus production. Conventionally, wheat straw based synthetic compost is used for its production. Use of paddy straw as such tends to make the composting process anaerobic leading to low quality compost and low yields. In the present study, an alternative high yielding compost formulation based on paddy straw + maize stalks as a substitute to the existing wheat straw based compost has been made. The physicochemical characteristics of the composts revealed their moisture, $\mathrm{pH}$, temperature, $\mathrm{C}: \mathrm{N}$ ratio to be within the range of $58.7-67.3 \%, 6.4-7.9,42.1-76.4^{\circ} \mathrm{C}, 37.7: 1-16.6: 1$ respectively. During different stages of mushroom cultivation i.e. at zero day of compost, final grade compost, pin head stage, after first flush and at crop termination the straw was analysed for proximate composition. NDF, ADF, Cellulose and hemicellulose content was significantly reduced upto pin head stage and ranged from $(70.20-46.20 \%),(52.41-33.72 \%)$, (36.37$20.69 \%)$, (17.59-8.57\%) respectively and stable thereafter in all the compost. Total ash content showed increment and ranged from 10.90-21.37\%. There was no decline in the lignin content during different stages of composting and crop production. Yield data indicated maximum yield (13.6 kg/q compost) in paddy straw + maize stalk (1:1) compost with 1563 fruit bodies/ q compost. It was observed that paddy straw + maize $(1: 1, \mathrm{w} / \mathrm{w})$ compost was better degraded than paddy straw + maize stalk $(2: 1$, w/w) and paddy straw composts. From the recent study, it was concluded that paddy straw + maize stalk $(1: 1$, w/w) compost was the best formulation which could be further exploited for large scale production of mushrooms for small and marginal farmers. 
room), Volvariella spp. (Paddy Straw Mushroom), Lentinula edodes (Shiitake mushroom) and Auricularia polytricha (Jew's ear mushroom) are commonly available edible mushrooms in Punjab. Some of them have been shown to possess wide beneficial properties such as antioxidant, anticancer, antimicrobial. The world production of mushrooms has increased from about from a meager one million tons in 1978 to about 27 million tons in 2012 (Royse, 2014). The current production of mushrooms in India has approximately more than one lakh ton mark with the annual growth rate of more than $15 \%$.

The button mushroom (Agaricus bisporus) is the most widely cultivated and consumed mushroom throughout the world contributing about $40 \%$ of total world mushroom production and about $80 \%$ of total mushrooms produced in India. The button mushroom is grown on composted substrates and a variety of substrates have been used in composting the world over. These composted substrates show huge variation in the yield of button mushroom indicating thereby the role of various physicochemical factors and the compositional changes in the substrate (Sharma, 1991) as these are important factors contributing to the composting process and hence to yield.

World production of agricultural wastes is about 4664.63 million tons, of which about 600 million tons is produced in India. According to a recent report, 5 per cent of the global biomass is burnt in India alone, contributing to ozone depletion (Tewari and Ahlawat, 2007). It is estimated that about 15 million tons of paddy straw is burnt in Punjab. Consequently, the growing of mushrooms on paddy straw is one such avocation, which if put into practice, can not only lead in improvement of dietary and economic standards of the masses, but also in combating environmental pollution due to burning of agro-waste. Moreover, paddy straw is cheaper and therefore can be profitably utilized for the mushroom production to combat the day by day increasing cost of mushroom production. Paddy straw though does not provide good physical structure to compost but gives good results when mixed with wheat straw in different ratios (Rana, 1998). The already recommended paddy straw formulations by PAU (Khanna and Kapoor, 2016) include wheat straw (WS) paddy straw (PS) $(1: 1, \mathrm{w} / \mathrm{w})$ and WS:PS (1:2, w/w). Ample amount of the paddy straw is available in Punjab in the season of September-March which is favourable for the growth of Agaricus bisporus. Therefore, it can solve the problem of storage of wheat straw for use in winter. Moreover, wheat straw is not available easily in areas where paddy is grown due to heavy transportation costs e.g. Southern India. Therefore, paddy straw could be used for compost preparation in button mushroom.

Maize is the third most important food crops after rice and wheat. Huge quantities of biomass are generated after harvest of the cobs and farmers have the practice of burning it in the field itself. This residue can be exploited for mushroom cultivation as maize stalks are rich in cellulose (44\%) and lignin (14.34\%) which can be used by button mushroom for its growth. Further, paddy straw + chopped maize stalks in combination could provide the desirable physicochemical characteristics required for compost preparation for button mushroom production.

\section{Materials and Methods}

The present investigation was carried at Mushroom Research Complex, Department of Microbiology, Punjab Agricultural University, Ludhiana. Long method composting used for preparation of wheat straw based compost as per the method of Khanna and Kapoor (2016) was followed. The substrates i.e. paddy straw 
and maize stalks were chopped to 4-6" sized and different compost formulations composing paddy straw: maize stalk $(1: 1,2: 1 \mathrm{w} / \mathrm{w})$ was prepared. Paddy straw and maize stalk mixture were spread on the cemented floor and wetted thoroughly for $48 \mathrm{~h}$ in the form of loose heap to achieve $70-75 \%$ moisture content. Wheat bran (dry) mixed with four chemical fertilizers was moistened with water and kept covered overnight to facilitate solubilization and absorption of chemical fertilizers onto the bran. The mixture was evenly broadcasted on wetted wheat straw, mixed thoroughly and stacked. The whole mixture was made to compact rectangular pile of $5^{\prime} x 5^{\prime} x 5^{\prime}$. Seven periodic turns were given, first three turnings on every fourth day and other four turnings on every third day. A turning schedule of 0 , $4,8,12,15,18,21$ and 24 day was followed. At every turn approximately $30 \mathrm{~cm}$ layer was separated from all the exposed surfaces of the pile, mixed well and moistened. The remaining pile was dismantled and mixed well. T

he material was restacked in such a way that outer portion of pile was placed in centre of the new pile. Molasses, gypsum, furadan and $\gamma$ BHC were mixed at the time of first, third, fifth and seventh turning respectively. Two days after the last turn, the compost pile was lowered. Master culture and then generation spawn of Agaricus bisporus was prepared from slant culture on wheat grains in empty bottles using the standard methodology of (Garcha, 1997). Healthy, uncrumpled wheat grains were washed and boiled (Wheat grain: $\mathrm{H}_{2} \mathrm{O} ; 1: 25$, w/v) for $2 \mathrm{~h}$ to become tender without rupturing of the seed coat. The boiled grains were then mixed with gypsum (Lab grade) and chalk powder @ 2 and 4\% w/v, respectively. The grains were filled in clean glass bottles (500 ml capacity), cotton plugged and wrapped with paper strips. The bottles were steam sterilized at $20 \pm 1 \mathrm{lbs}$ for 90 min.One agar bit measuring approximately
$3 \times 1 \mathrm{~cm}$ was placed inside a bottles aseptically in such a way that the mycelial surface of bit was in close contact with the grains. These were incubated at $25 \pm 10^{\circ} \mathrm{C}$ for period of 20 days till mycelium completely covered the grains. Mushroom growing was carried out in polythene bags $(20$ " $\times 24$ "). Five $\mathrm{kg}$ of ready compost was filled to a depth of 10-12" per bag which was spawned thoroughly at the rate of 0.6 per cent on fresh weight basis of compost. Ten replicates for each of the three compost formulation were used for cultivation. The humidity in the room was maintained by spraying water on the floors and walls. The disinfected casing mixture was used @ 2.0-2.5 kg per bag to make a uniform thick casing layer of 1.5". Water was sprayed directly on cased bags till the end of cropping.

At each turning samples were drawn for recording various observations i.e. Temperature, moisture (AOAC 2000), pH (Sekhon et al., 1986), carbon content (Nelson and Sommers, 1996), nitrogen content by Kjedahl method (Kacar, 1994) and microbiological count (Vlassak et al., 1992).

For proximate analysis samples were collected at zero day of compost, final grade compost, pin head stage, after first flush and at crop termination. These samples were oven dried and ground to pass through 40 mesh and analysed for various fractions viz. Neutral detergent fibre, Acid detergent fibre, lignin, cellulose, hemicelluloses, crude protein and total ash as per AOAC (2000). Cultivation trials with commercial strain (U3) of Agaricus bisporus were carried out during winter season (November to March) on different types of composts developed. Yield related parameters including days for spawn run and case run, pinhead formation, total number of fruit bodies produced, average weight of fruit body, total weight of fruit bodies/bag, incidence of disease were recorded. 


\section{Statistical analysis}

All data were subjected to analysis of variance and the means were compared using "the least significant difference" test at 0.05 probability test.

\section{Results and Discussion}

\section{Physicochemical characteristic of different composts during composting}

The physicochemical characteristics of the compost mixtures namely paddy straw + maize stalks $(1: 1, \mathrm{w} / \mathrm{w})$, paddy straw + maize stalks $(2: 1, w / w)$ and paddy straw based compost as control were carried out at different turning stages of compost formation. The data for moisture, $\mathrm{pH}$, temperature, $\mathrm{C}: \mathrm{N}$ ratio and microbiological counts were recorded at each turning. The data has been tabulated in the table 1 .

The moisture content of the composts was observed to be $65.2 \%-67.3 \%$ in PS:MS (2:1, $1: 1, \mathrm{w} / \mathrm{w})$ respectively at the start of the composting which finally decreased to $61.3 \%$ $63.4 \%$ in PS:MS (2:1, 1:1,w/w) respectively at the time of spawning whereas for the paddy straw (control) it was $62.6 \%$ in the beginning of compost formation while at the time of spawning, it was observed to be $62.1 \%$. The $\mathrm{pH}$ profile of two composts viz., paddy straw + maize stalks $(1: 1, \mathrm{w} / \mathrm{w})$, paddy straw + maize stalks $(2: 1, \mathrm{w} / \mathrm{w})$ showed a similar pattern during composting. The $\mathrm{pH}$ was recorded as 6.4-6.7 for PS:MS (1:1, 2:1, w/w) respectively at the start of the composting which gradually increased to 7.6-7.8 for PS:MS (2:1, 1:1, w/w) respectively between the turnings and finally declined to7.2-7.3 in PS:MS (2:1, 1:1, w/w) respectively at the time of spawning while in case of paddy straw compost the $\mathrm{pH}$ increased from 6.5 at the start of composting and finally reached to 7.9 at the time of spawning.
In the composts, the temperature of the middle zone of the stack was higher than the upper and the lower zone. The temperature of the compost stack was maximum at $4^{\text {th }}$ turning ranging from 73.4 to $76.4^{\circ} \mathrm{C}$ in all the composts. The high temperature in the composting stack is an important parameter which favours the growth of thermophilic microflora also but brings some chemical changes that are essential for the selectivity of the compost. The C:N ratio of the composts progressively narrowed down from the beginning towards the end of composting i.e. $37.7: 1$ to $16.6: 1$. The $\mathrm{C}: \mathrm{N}$ ratio of the final grade compost was 18.7:1 in control (paddy straw based compost) while it was 16.6:1 and 17.2:1 in paddy straw + maize stalks compost $(1: 1 ; 2: 1)$, respectively. The bacterial count of mesophiles was observed maximum at $2^{\text {nd }}$ turning ranged from 22-24 cfu while that of thermophiles it was maximum in $4^{\text {th }}$ turning which ranged from 130-134 cfu in all the composts. In case of fungal count, the mesophiles showed highest count at $2^{\text {nd }}$ turning ranged from 7.33-8.0 cfu whereas thermophiles were maximum at $4^{\text {th }}$ turning which ranges from 7.0-7.33 cfu in all the composts.

The optimum moisture content for biodegradation can vary widely for different compost mixtures and times in the composting process, ranging from near 50 to over $70 \%$ on a wet basis (Richard et al., 2002).During composting, large quantity of water can evaporate in order to control excessive temperature and as water content diminishes the rate of decomposition decreases, then rewetting should be required in order to maintain the optimum moisture content for the microbial activity (Bernal et al., 2009). Kaur and Khanna (2001) reported that the moisture content of three compost namely wheat straw + paddy straw $(1: 1, \mathrm{w} / \mathrm{w})$, wheat straw + paddy straw $(1: 2, \mathrm{w} / \mathrm{w})$ and paddy straw alone was observed to be in the range of $59-72 \%$. 
Kaur and Khanna (2001) showed the $\mathrm{pH}$ range of 6.9-8.3 for different compost formulations. The $\mathrm{pH}$ decreased at the beginning of the composting due to the rapid degradation of readily available $\mathrm{OM}$ and accumulation of organic acids (Pandey et al., 2016) while later on, gradually increased $\mathrm{pH}$ might be ascribed to the degradation of proteinaceous materials and the accumulation of ammonium (Zhang and Sun 2016).

While studying the physiological attributes of paddy straw based synthetic compost, Subramanyam (1998) reported that achieving $61^{\circ} \mathrm{C}$ and $58^{\circ} \mathrm{C}$ in compost and air temperature respectively during warming up was considered as adequate activity in the compost. Temperature variations during composting are the result of the thermal balance between the heat generated by the microorganisms and the heat loss through convection, conduction, evaporation, and radiation (Santos et al., 2016). The trend of temperature in the composting pile has been also observed by Kaur and Khanna (2001). The maximum temperature achieved was $69^{\circ}$ $\mathrm{C}$ for wheat straw compost, $67^{\circ} \mathrm{C}$ for both wheat straw + paddy straw $(1: 1$, w/w $)$ and paddy straw alone. Based on physiochemical study of $A$. bisporus compost, an ideal compost should have $\mathrm{C}: \mathrm{N}$ between 15-21:1 and not greater than 30:1 (Fidanza and Beyer 2009). Kaur and Khanna (2001) reported that the $\mathrm{C}: \mathrm{N}$ ratio at the beginning was 32.6:1 in paddy straw compost and at the end of composting, the $\mathrm{C}: \mathrm{N}$ ratio ranged from 16.3:119.3:1 in different composts.

\section{Proximate analysis of compost}

Mushroom compost prepared with paddy straw and maize stalk $(1: 1 ; 2: 1$, w/w) was compared with paddy straw based standard compost. The compost was analysed for proximate composition at zero day of compost, final grade compost, pin head stage, after first flush and at crop termination. The data has been tabulated in the table 2 and 3 . The neutral detergent fibre was significantly reduced in all the compost formulation upto pin head stage and there after it was statistically at par after first flush and at crop termination. As the acid detergent fibre was also significantly reduced in all the compost till pin head stage. Total ash content in all the compost showed increment and ranged. There was no significant variation in crude protein content at these stages. The cellulose and hemi-cellulose content was reduced drastically during the compost formulations leading toward pin head stage and it was stable thereafter. The lignin content showed no significant decline during different stages of composting and crop production.

The substrate composition of different composts WS + PS (1:1,1:2, w/w) and PS depicted a progressive decrease of various constituents: NDF, ADF, cellulose, hemicelluloses (Kaur, 2000). Cellulose, hemicelluloses and lignin which constitute the major part of plant waste are known to have direct impact on the growth and development of mushroom fungi (Zadrazil, 1975). Moorthy (1981) and Singh et al., (1989) observed that cellulose, hemicelluloses and lignin are degraded up to an extent of $75 \%$ during the growth period. During the growth of mushroom, the cellulose content of substrates was reduced with maximum rate in fruitification stage compared to spawn run stage.

Yield potential of Agaricus bisporus of U3 Strain on paddy straw and maize stalk based composts

Paddy straw and maize stalk were used in 1:1, $2: 1(\mathrm{w} / \mathrm{w})$ ratio to prepare compost for the cultivation of Agaricus bisporus U3 strain. The data has been tabulated in the table 4 . 
Table.1 Physical, chemical and microbiological properties of different compost formulations

\begin{tabular}{|c|c|c|c|c|c|c|c|c|c|}
\hline \multirow[t]{3}{*}{ COMPOST } & \multirow{3}{*}{$\begin{array}{l}\text { TURNING } \\
\text { (NO.) }\end{array}$} & \multicolumn{3}{|c|}{ PHYSICAL PROPERTIES } & \multirow{3}{*}{$\begin{array}{l}\text { CHEMICAL } \\
\text { PROPERTIES } \\
\text { C:N }\end{array}$} & \multicolumn{4}{|c|}{ MICROBIOLOGICAL COUNT } \\
\hline & & \multirow{2}{*}{$\begin{array}{l}\text { MOISTURE } \\
(\%)\end{array}$} & \multirow[t]{2}{*}{ pH } & \multirow{2}{*}{$\begin{array}{l}\text { TEMPERATURE } \\
\left({ }^{\circ} \mathrm{C}\right)\end{array}$} & & \multicolumn{2}{|c|}{ BACTERIAL $\left(\times 10^{5} \mathrm{cfu}^{-1}\right.$ compost $)$} & \multicolumn{2}{|c|}{ FUNGAL $\left(\times 10^{2} \mathrm{cfu}^{-1}\right.$ compost $)$} \\
\hline & & & & & & MESOPHILIC & THERMOPHILIC & MESOPHILIC & THERMOHILIC \\
\hline $\begin{array}{l}\text { I } \\
\text { PS:MS } \\
(\mathbf{1 : 1 )}\end{array}$ & $\begin{array}{l}1 \\
2 \\
3 \\
4 \\
5 \\
6 \\
7\end{array}$ & $\begin{array}{l}67.3 \\
63.1 \\
61.7 \\
60.6 \\
62.2 \\
61.8 \\
63.4\end{array}$ & $\begin{array}{l}6.4 \\
6.6 \\
7.0 \\
7.4 \\
7.8 \\
7.5 \\
7.3\end{array}$ & $\begin{array}{l}59.2 \\
64.1 \\
71.5 \\
73.4 \\
67.2 \\
54.3 \\
42.1\end{array}$ & $\begin{array}{l}32.3: 1 \\
26.4: 1 \\
23.9: 1 \\
21.2: 1 \\
19.2: 1 \\
17.1: 1 \\
16.6: 1\end{array}$ & $\begin{array}{l}18 \\
23 \\
13 \\
16 \\
21 \\
20 \\
18\end{array}$ & $\begin{array}{l}80 \\
113 \\
129 \\
134 \\
87 \\
58 \\
21\end{array}$ & $\begin{array}{l}5.33 \\
7.67 \\
4.33 \\
3.67 \\
2.33 \\
1.67 \\
1.33\end{array}$ & $\begin{array}{l}3.33 \\
4.33 \\
6.33 \\
7.00 \\
3.33 \\
2.33 \\
2.00\end{array}$ \\
\hline \multicolumn{2}{|l|}{ CD 5\% } & NS & NS & 3.44 & 0.66 & 4.72 & 8.50 & 2.22 & 2.44 \\
\hline $\begin{array}{l}\text { II } \\
\text { PS:MS } \\
(2: 1)\end{array}$ & $\begin{array}{l}1 \\
2 \\
3 \\
4 \\
5 \\
6 \\
7\end{array}$ & $\begin{array}{l}65.2 \\
64.3 \\
61.6 \\
60.1 \\
62.3 \\
63.2 \\
61.3\end{array}$ & $\begin{array}{l}6.7 \\
7.1 \\
7.3 \\
7.6 \\
7.5 \\
7.3 \\
7.2\end{array}$ & $\begin{array}{l}58.3 \\
66.2 \\
72.3 \\
76.4 \\
65.4 \\
53.1 \\
43.7\end{array}$ & $\begin{array}{l}37.7: 1 \\
33.3: 1 \\
27.0: 1 \\
23.6: 1 \\
20.6: 1 \\
18.2: 1 \\
17.2: 1\end{array}$ & $\begin{array}{l}18 \\
22 \\
14 \\
18 \\
20 \\
21 \\
16\end{array}$ & $\begin{array}{l}84 \\
102 \\
125 \\
131 \\
83 \\
61 \\
23\end{array}$ & $\begin{array}{l}4.67 \\
7.33 \\
4.30 \\
3.33 \\
2.33 \\
1.67 \\
1.33\end{array}$ & $\begin{array}{l}3.33 \\
4.33 \\
5.67 \\
7.00 \\
3.33 \\
1.67 \\
1.33\end{array}$ \\
\hline \multicolumn{2}{|l|}{ CD $5 \%$} & NS & NS & 3.26 & 1.05 & NS & 9.17 & 2.12 & 2.56 \\
\hline $\begin{array}{l}\text { III } \\
\text { CONTROL } \\
\text { (PS) }\end{array}$ & $\begin{array}{l}1 \\
2 \\
3 \\
4 \\
5 \\
6 \\
7\end{array}$ & $\begin{array}{l}62.6 \\
60.3 \\
58.7 \\
59.4 \\
61.3 \\
63.2 \\
62.1\end{array}$ & $\begin{array}{l}6.5 \\
6.9 \\
7.2 \\
7.5 \\
7.6 \\
7.8 \\
7.9\end{array}$ & $\begin{array}{l}64.4 \\
67.9 \\
69.7 \\
74.4 \\
65.1 \\
55.6 \\
42.3\end{array}$ & $\begin{array}{l}35.2: 1 \\
30.6: 1 \\
25.7: 1 \\
23.5: 1 \\
20.2: 1 \\
19.2: 1 \\
18.7: 1\end{array}$ & $\begin{array}{l}18 \\
24 \\
14 \\
9.7 \\
6.3 \\
5.7 \\
4.7 \\
\end{array}$ & $\begin{array}{l}87 \\
110 \\
132 \\
130 \\
92 \\
64 \\
39\end{array}$ & $\begin{array}{l}5.33 \\
8.00 \\
4.67 \\
3.67 \\
2.00 \\
1.67 \\
1.33\end{array}$ & $\begin{array}{l}3.67 \\
5.00 \\
6.33 \\
7.33 \\
2.67 \\
1.33 \\
1.00\end{array}$ \\
\hline \multicolumn{2}{|l|}{ CD 5\% } & NS & NS & 2.76 & 0.61 & 3.70 & 11.46 & 2.26 & 1.42 \\
\hline
\end{tabular}

PS:MS- Paddy straw: Maize stalks, Control-Paddy straw, C:N- Carbon:Nitrogen 
Table.2 Proximate analysis of compost during different stages of growth of button mushroom

\begin{tabular}{|c|c|c|c|c|c|}
\hline Compost & Intervals & $\begin{array}{c}\text { Neutral } \\
\text { Detergent } \\
\text { Fibre } \\
(\%)\end{array}$ & $\begin{array}{c}\text { Acid Detergent } \\
\text { Fibre }(\%)\end{array}$ & $\begin{array}{c}\text { Total } \\
\text { Ash (\%) }\end{array}$ & $\begin{array}{c}\text { Crude } \\
\text { Protein } \\
(\%)\end{array}$ \\
\hline \multirow{5}{*}{$\begin{array}{c}\text { I } \\
\text { Paddy } \\
\text { straw:Maize } \\
\text { stalk (1:1) }\end{array}$} & $\mathrm{T} 1$ & 70.20 & 52.41 & 10.90 & 15.23 \\
\hline & $\mathrm{T} 2$ & 52.93 & 41.43 & 13.63 & 12.17 \\
\hline & $\mathrm{T} 3$ & 48.23 & 36.04 & 16.83 & 10.43 \\
\hline & $\mathrm{T} 4$ & 45.03 & 29.19 & 18.73 & 9.20 \\
\hline & T5 & 43.70 & 26.85 & 21.33 & 8.80 \\
\hline \multicolumn{2}{|c|}{ CD (5\%) } & 3.50 & 3.00 & 2.98 & 2.65 \\
\hline \multirow{5}{*}{$\begin{array}{c}\text { II } \\
\text { Paddy } \\
\text { straw:Maize } \\
\text { stalk (1:2) }\end{array}$} & $\mathrm{T} 1$ & 68.23 & 52.03 & 11.20 & 14.80 \\
\hline & $\mathrm{T} 2$ & 54.73 & 40.57 & 13.63 & 11.80 \\
\hline & T3 & 46.20 & 35.32 & 16.77 & 10.23 \\
\hline & $\mathrm{T} 4$ & 44.17 & 30.34 & 18.73 & 9.03 \\
\hline & T5 & 39.50 & 28.24 & 21.37 & 8.44 \\
\hline \multicolumn{2}{|c|}{ CD (5\%) } & 3.37 & 1.34 & 2.94 & 2.97 \\
\hline \multirow{5}{*}{$\begin{array}{l}\text { III } \\
\text { Paddy straw } \\
\text { (control) }\end{array}$} & $\mathrm{T} 1$ & 69.27 & 49.04 & 10.93 & 13.85 \\
\hline & $\mathrm{T} 2$ & 54.83 & 38.78 & 13.87 & 10.82 \\
\hline & T3 & 47.30 & 33.72 & 16.50 & 9.55 \\
\hline & $\mathrm{T} 4$ & 43.20 & 28.94 & 18.57 & 8.68 \\
\hline & T5 & 41.73 & 26.94 & 21.20 & 7.94 \\
\hline \multicolumn{2}{|c|}{ CD (5\%) } & 3.00 & 2.60 & 3.62 & 2.14 \\
\hline
\end{tabular}

T1 - Fresh chopped straw (first day), T2 - Final grade compost (at $28^{\text {th }}$ day), T3 - Pinhead stage, T4 - After first flush, T5 - At crop termination 
Table.3 Proximate analysis of compost during different stages of growth of button mushroom

\begin{tabular}{|c|c|c|c|c|}
\hline Compost & Intervals & Cellulose (\%) & Lignin (\%) & Hemicellulose (\%) \\
\hline \multirow{5}{*}{$\begin{array}{l}\text { I } \\
\text { Paddy straw:Maize stalk } \\
(1: 1)\end{array}$} & $\mathrm{T} 1$ & 31.72 & 10.80 & 15.90 \\
\hline & $\mathrm{T} 2$ & 23.72 & 9.84 & 14.45 \\
\hline & T3 & 20.69 & 9.03 & 12.87 \\
\hline & $\mathrm{T} 4$ & 17.89 & 8.67 & 10.17 \\
\hline & T5 & 16.73 & 8.06 & 9.36 \\
\hline \multicolumn{2}{|l|}{ CD $(5 \%)$} & 2.16 & NS & 0.79 \\
\hline \multirow{5}{*}{$\begin{array}{l}\text { II } \\
\text { Paddy straw:Maize stalk } \\
(1: 2)\end{array}$} & $\mathrm{T} 1$ & 34.79 & 11.15 & 17.59 \\
\hline & $\mathrm{T} 2$ & 26.39 & 10.70 & 15.39 \\
\hline & T3 & 22.71 & 9.73 & 12.28 \\
\hline & $\mathrm{T} 4$ & 19.69 & 8.68 & 9.07 \\
\hline & T5 & 18.34 & 7.56 & 8.41 \\
\hline \multicolumn{2}{|l|}{ CD (5\%) } & 2.68 & NS & 0.83 \\
\hline \multirow{5}{*}{$\begin{array}{l}\text { III } \\
\text { Paddy straw (control) }\end{array}$} & $\mathrm{T} 1$ & 36.37 & 9.97 & 12.33 \\
\hline & $\mathrm{T} 2$ & 27.04 & 9.07 & 10.97 \\
\hline & T3 & 23.40 & 8.45 & 8.57 \\
\hline & $\mathrm{T} 4$ & 20.05 & 8.25 & 7.86 \\
\hline & T5 & 19.05 & 8.18 & 7.80 \\
\hline \multicolumn{2}{|l|}{ CD (5\%) } & 3.08 & NS & 0.66 \\
\hline
\end{tabular}

Table.4 Yield potential of Agaricus bisporus of U3 strain on paddy straw, maize stalk based composts

\begin{tabular}{|l|c|c|c|c|c|c|c|}
\hline Compost Formulation & $\begin{array}{c}\text { Spawn } \\
\text { run (d) }\end{array}$ & $\begin{array}{c}\text { Case } \\
\text { run } \\
\text { (d) }\end{array}$ & $\begin{array}{c}\text { Pinning } \\
\text { (d) }\end{array}$ & $\begin{array}{c}\text { Yield } \\
\text { (kg/q } \\
\text { compost) }\end{array}$ & $\begin{array}{c}\text { NFB } \\
\text { (no./q } \\
\text { compost) }\end{array}$ & $\begin{array}{c}\text { Av. Wt. of } \\
\text { a FB (g) }\end{array}$ & $\begin{array}{c}\text { Disease/ } \\
\text { Pest }\end{array}$ \\
\hline $\begin{array}{l}\text { Paddy straw + Maize } \\
\text { stalk (1:1) }\end{array}$ & $21-28$ & 27 & 48 & 13.6 & 1563 & 8.7 & negative \\
\hline $\begin{array}{l}\text { Paddy straw + Maize } \\
\text { stalk (2:1) }\end{array}$ & $21-24$ & 25 & 47 & 10.6 & 1040 & 10.2 & positive \\
\hline Paddy straw (control) & $24-27$ & 25 & 51 & 9.9 & 805 & 12.3 & negative \\
\hline CD (5 \%) & & & & 1.57 & 103.3 & & \\
\hline
\end{tabular}

$\mathrm{NFB}=$ Number of fruit bodies 
The observations on spawn run, case run, yield harvest and number of fruit bodies were made for 4 weeks of the harvesting. Spawn run in all compost formulations was found to complete between 21 to 28 days. The mycelial growth was visually fast on paddy straw + maize stalk based composts. Case run was completed between 25-27 days and pinning appeared between 47 to 51 days of spawning. Yield data indicated maximum yield $(13.6 \mathrm{~kg} / \mathrm{q}$ compost) in paddy straw + maize stalk (1:1) compost with 1563 fruit bodies/ q compost (Fig. 1 and 2, Plate 1). Yield data obtained for paddy straw + maize stalk (2:1) was at par with that of the paddy straw based compost. Average weight of fruit bodies ranged from 8.7-12.3 g. In certain bags (5-7 bags) of paddy straw + maize stalk (2:1) showed presence of green mould with a loss of about $2 \%$ of yield. It was observed that paddy straw + maize $(1: 1, \mathrm{w} / \mathrm{w})$ compost was better degraded than paddy straw + maize stalk $(2: 1, \mathrm{w} / \mathrm{w})$ and paddy straw composts. This showed that the compactness of paddy straw compost stack is an obstacle to the propagation of thermophilic microorganisms that are responsible for the proper degradation of the compost which was directly related to the yield. The utilization of paddy straw and maize stalks as a substitute of wheat straw delivered a yield practically identical to wheat straw was observed by Tewari and Sohi (1976). They found that synthetic compost prepared out of maize stalks and paddy straw when mixed in equal proportions produced a yield of $145.5 \mathrm{~kg} /$ ton of dry matter, which was quite comparable to wheat straw compost. Shandilya (1989) found high yield of button mushroom in two formulations of paddy straw composts with horse manure $(5: 1, \mathrm{w} / \mathrm{w})$ and chicken manure $(2.5: 1, \mathrm{w} / \mathrm{w})$. Two formulations of compost with WS+PS $(1: 1, w / w)$ and WS + PS $(1: 2, w / w)$ have been recommended by PAU for the growers (Garcha, 1997; Khanna and Kapoor, 2016). Kaur and Khanna (2001) evaluated two synthetic compost preparations; WS+PS (1:1) and WS+PS (1:2) and obtained yields ranging from 17.9-23.7 kg/100kg compost. Singh (1997) utilized different proportions of wheat straw and paddy straw with sugarcane baggase during composting.

In conclusion the growth of mushrooms fully depends upon the compost for their nutrition. The efficiency of the mushrooms to utilize the various constituents of compost depend upon the substrate used in composting which further depends upon many physiochemical factors responsible during the composting process and mushroom growth. Yield data indicated maximum yield (13.6 kg/q compost) in paddy straw + maize stalk $(1: 1$, w/w $)$ compost with 1563 fruit bodies/ q compost. It was observed that paddy straw + maize $(1: 1$, w/w) compost was better degraded than paddy straw + maize stalk $(2: 1, \mathrm{w} / \mathrm{w})$ and paddy straw composts. From the recent study, it was concluded that paddy straw + maize stalk $(1: 1, w / w)$ compost was the best formulation which could be further exploited for large scale production of mushrooms for small and marginal farmers.

\section{Acknowledgements}

The authors would like to thank the Department of Microbiology, Punjab Agricultural University for providing laboratory facilities.

\section{References}

AOAC (2000) Official methods of analysis of $A O A C$. International 17th edition; Gaithersburg, MD, USA Association of Analytical Communities. https://law.resource.org/pub/us/cfr/ibr/ 002/aoac.methods

Bernal M P, Alburquerque J A, Moral R (2009) Composting of animal manures and chemical criteria for compost 
maturity assessment: a review. Bioresour Technol 100 (22): 5444-53. https://doi.org/10.1016/j.biortech.2008 .11 .027

Borchers A T, Keen C L and Gershwin M E (2004) Mushrooms, tumors, and immunity: an update. ExpBiol Med (Maywood) 229: 393-406.https://DOI: 10.1155/MI.2005.63

Chang R (1996) Functional properties of edible mushrooms. Nutr Rev 54: S91S93.https://doi.org/10.1111/j.17534887.1996.tb03825.x

Fidanza M A and Beyer D M (2009) Plant nutrients and fresh mushroom compost. Mush News12: 78-83.

Garcha H S (1997) A manual of Mushroom Growing. Punjab Agricultural University Press, Ludhiana.

Kaur H and Khanna P K (2001) Physicochemical and microbiological characteristics of paddy straw based compost for Agaricus bisporus production. Indian J Mush2: 15-20.

Kaur P (2000) Ligninolytic ezymes of Pleurotus spp. in relation to substrate utilization. Dissertation, Punjab Agricultural University, Ludhiana.

Khanna P K and Kapoor S (2016) Mushroom Growing Bulletin. Punjab Agricultural University, Ludhiana, pp. 78.

Moorthy V K (1981) Microbial and chemical studies on the cultivation of oyster mushroom (Pleurotus sajar caju) in paddy straw. European $J$ Appl Microbiol Biotechnol12: 58-61.

Murugkar A D and Subbulakshmi G (2005) Nutritional value of edible wild mushrooms collected from the Khasi hills of Meghalaya. Food Chem 89: 599-603. https://doi.org/10.1016/j. foodchem.2004.03.042

Nelson D W and Sommers (1996) Total Carbon, organic carbon and organic matter. In: Page A. (ed.) Methods of Soil Analysis. Science Society of
America and American Society of Agronomy, Madison, Wisconsin, 9611010.

Pandey P K, Vaddella V, Cao W, Biswas S, Chiu C, Hunter s (2016) In-vessel composting system for converting food and green wastes into pathogen free soil amendment for sustainable agriculture. J cleanProd139: 40715.https://doi.org/10.1016/j.jclepro.20 16.08 .034

Rana R S (1998) Compost and composting for white button mushroom. Lecture Compendium of Recent Advances in Mushroom Cultivation. Academy of Agricultural Research and Education Management, HAU, Hisar. November 10-21. pp 21-33.

Ribeiro L R and Salvadori D M (2003) Dietary components may prevent mutation-related diseases in humans. Mutat Res 544: 195-201. https://www.ncbi.nlm.nih.gov/pubmed $/ 14644321$

Richard T L, Hamelers H V M, Veeken A, Silva T (2002) Moisture Relationships in Composting Processes. Compost sci util., 10(4):286-302. https://doi.org/10. 1080/1065657x.2002.10702093

Royse D J (2014) A global perspective on the high five: Agaricus, Pleurotus, Lentinula, Auricularia \& Flammulina. Proceedings of the $8^{\text {th }}$ International Conference on Mushroom Biology and Mushroom Products (ICMBMP8) 2014. Pp 1-6. http://www.wsmbmp. org/1/01.pdf

Santos A, Bustamante MA, Tortosa G, Moral R, Bernal MP (2016) Gaseous emissions and process development during composting of pig slurry: the influence of the proportion of cotton gin waste. J. Clean Prod112:8190. DOI: 10.3303/CET1761173

Sekhon G S, Chibba I M and Arora C L (1986) Introduction to soil fertility 
(Part II). In Soil Science Laboratory Manual. College of Agriculture, Punjab Agricultural University, Ludhiana.

Shandilya T R (1989) Studies on casing soil media during the cultivation of Agaricus bisporus. Compost Science and utilization 4: 6-17.

Sharma H S (1991) Biochemical and thermal analysis of mushroom compost during preparation. In: Maher M J (ed) Science and Cultivation of Edible Fungi Balkema, Rotterdam, pp 16979.

Singh B, Makkar H P S, Negi S S (1989) Rate and extent of digestion and potentially digestible dry matter and cell wall of various tree leaves. $J$ Dairy Sci., 72(12): 3233-39. http://dx.doi.org/10. 3168/jds.S0022-0302(89)79482-0

Singh RP (1997) Studies on the base materials of compost in particular reference to the Agaricus bisporus (Lange) Sing. Cultivation. Indian Mushroom Conference. Souvenir and Abstracts, MSI, Solan, Sept. 10-12, pp. 41.

$\begin{array}{lllll}\text { Subrahmanyam } & \text { S } & \text { V } & \text { S } & \text { (1998) }\end{array}$ Physicochemical attributes of various batches of paddy straw compost in a commercial unit. Mushroom Res7: 2934.

Tewari R P and Ahlawat O P (2007) Recycling of Agro-wastes from microbial protein production through mushroom production. Souvenir cum Abstracts - International Conference on Mushrooms and Biotechnology held at National Research Centre for Mushroom, Solan on Feb 10-11, 2007. Mushroom Society of India. Abstr pp. 85.

Tewari R P and Sohi H S (1976) Studies on use of paddy straw and maize stalks as a substitute for wheat straw to prepare synthetic compost for the cultivation of white European mushroom, Agaricus bisporus (Lange) Sing. Indian J Mushroom2: 18-20.

Vlassak K L, Holm L V and Duchateau $\mathrm{L}(1992)$ Isolation and characterization of fluorescent Pseudomonas associated with roots of rice and banana grown in Srilanka. Plant and Soil145: 51-63.

Zadrail F (1975) Effect of different heat pretreatments of wheat straw on its microbial activity and colonization by different tropical and sub-tropical edible mushrooms. World J Microbiol Biotechnol., 10(4): 374-80.

Zhang L, Sun X (2016) Influence of bulking agents on physical, chemical and microbiological properties during the two stage composting of green waste. Waste Manag48: 115-26. https://doi.org/10.1016/j.wasman.2015 .11 .032

\section{How to cite this article:}

Sukhmandeep Kaur, Mehakpreet Kaur, Rajni Devi and Shammi Kapoor. 2019. Paddy Straw and Maize Stalks Compost for Cultivation of Agaricus Bisporus. Int.J.Curr.Microbiol.App.Sci. 8(01): 2418-2428. doi: https://doi.org/10.20546/ijcmas.2019.801.255 